\title{
PENGARUH PEMBELAJARAN ONLINE TERHADAP MOTIVASI BELAJAR MAHASISWA SEMESTER GENAP PROGRAM STUDI PENDIDIKAN EKONOMI TAHUN AKADEMIK 2020/2021
}

\author{
Suryadi ${ }^{1,}$ Ahmad Hafas Rasyidi ${ }^{2}$, Nursalam ${ }^{3}$ \\ ${ }^{1}$ Mahasiswa Prodi Pendidikan Ekonomi STKIP PGRI Situbondo \\ ${ }^{2,3}$ Dosen Pendidikan Ekonomi STKIP PGRI Situbondo \\ Corresponding Email:_Suryadioyye1997@gmail.com
}

\begin{abstract}
ABSTRAK
Penelitian ini bertujuan untuk mengetahui pengaruh pembelajaran online terhadap motivasi belajar mahasiswa STKIP PGRI Situbondo semester genap program studi pendidikan ekonomi tahun akademik 2020/2021. Penelitian ini menggunakan penelitian Ex Post Facto. Populasi dalam penelitian ini yaitu mahasiswa semester 2, 4 dan 6 Program Studi Pendidikan Ekonomi STKIP PGRI Situbondo. Pengumpulan data dalam penelitian ini dilakukan dengan menggunakan observasi, wawancara, angket, dan dokumentasi dan selanjutnya dianalisis dengan Uji Chi Kuadrat. Dari hasil analisis data yang diperoleh Hal ini dibuktikan dari hasil analisis yang menggunakan korelasi sederhana product moment diperoleh nilai koefisien korelasi sebesar 0,47 . Setelah dikonsultasikan dengan tabel interpretasi diatas maka nilai 0,44 terletak antara $\pm 0,41$ s.d $\pm 0,60$ maka tingkat korelasi antara pengaruh pembelajaran online terhadap motivasi belajar mahasiswa ialah korelasi sedang. Hasil pengujian hipotesis selengkapnya adalah sebagai berikut : Harga rtabel $\left(\mathrm{X}^{2}\right)$ dengan derajat kebebasan $(\mathrm{db})=1$ pada tabel taraf signifikasi $5 \%=3,841$. Sedangkan harga $\mathrm{r}_{\text {hit }}$ sebesar $=11,59$. Jadi harga $r_{\text {hit }} 11,59>$ harga $r_{\text {tab }} 3,841$, Jadi $r_{\text {hit }}$ lebih besar dari $r_{\text {tab }}$ artinya hipotesis nihil (Ho) ditolak,dan hipotesis kerja (Ha) diterima, berarti Ada pengaruh pembelajaran online terhadap motivasi belajar mahasiswa.
\end{abstract}

Kata Kunci: Pembelajaran Online, Motivasi Belajar

\section{PENDAHULUAN}

Menurut Rais M (2010), pendidikan merupakan kebutuhan manusia yang harus selalu berkembang sesuai dengan perubahan zaman yang ada. Perkembangan yang semakin pesat di dunia pendidikan dan teknologi menjadi acuan untuk kualitas pendidikan yang ada di Indonesia. Perkembangan ini berlangsung secara cepat dan terus menerus sehingga membuat kementerian pendidikan nasional (Kemdiknas) menekankan pada 
penyelenggara layanan prima pendidikan nasional untuk membentuk insane Indonesia cerdas komprehensif. Dalam pembelajaran online adalah satu-satunya media pembelajaran yang dapat memudahkan bagi siapa saja yang ingin melanjutkan kejenjang diploma ataupun sarjana tanpa harus bersusah payah datang ketempat proses pembelajaran berlangsung. Bentuk dari perkembangan teknologi informasi yang diterapkan di dunia pendidikan adalah pembelajaran online.

STKIP PGRI Situbondo adalah salah satu lembaga pendidikan tinggi yang bertugas menyiapkan mahasis wamenja dilulusan yang berkualitas. Kualitas pembelajaran yang baik merupakan hal yang sangat penting untuk dicapai dalam setiap proses pembelajaran. Hal ini di karenakan menyiapkan lulusan/output yang siapbekerjadimasyarakat. Idealnya output yang baikakanmenghasilkan outcome yang baik.

Lulusan yang memiliki kualitas yang baik akan mudah mendapatkan pekerjaan sesuai yang diharapkan, dan mampu bekerja secara professional yang akan menumbuhkan kepercayaan dan nama baik untuk almamater. Sesuai dengan beberapa definisi tentang kualitas pembelajaran dan indicator yang telah disebutkan di atas, dapat dikatakan bahwa kualitas pembelajaran di STKIP PGRI Situbondo dipengaruhi oleh beberapa faktor, di antaranya adalah dosen dan mahasiswa sebagai input dan media pembelajaran yang digunakan untuk menunjang proses pembelajaran.

Media pembelajaran online berpengaruh terhadap kualitas pembelajaran. Hal ini senada dengan Putranti (2013), yang mengungkapkan bahwa salah satu manfaat media pembelajaran adalah meningkatkan kualitas indeks prestasi komulatif. Sejalan dengan itu, Depdiknas juga menyatakan bahwa indicator kualitaspembelajaran salah satunyaadalah media pembelajaran. Media pembelajaran online berperan penting dalam menunjang pemahaman mahasiswa, terlebih pada saat pembelajaran online seperti saat ini.

Akan tetapi dalam penggunannya, seringkali menimbulkan berbagai kendala kepada mahasiswa. Pengamatan awal pada mahasiswa, menunjukkan tidak semua mahasiswa dapat bergabung kedalam kelas saat dilakukan perkuliahan secara online.

\section{3 | JURNAL IKA PGSD UNARS VOL. 10 No. 2 DESEMBER 2021}


Hal ini disebabkan banyak faktor, diantaranya adalah tidak tersedianya jaringan internet di masing-masing tempat, dan biaya kuota yang menguras uang saku mahasiswa. Permasalahan tersebut dikhawatirkan mengganggu tercapainya tujuan pembelajaran yang berkualitas untuk setiap mahasiswa.

Mahasiswa merupakan salah satu input penting dalam proses pembelajaran. Kemampuan awal mahasiswa menjadi salah satu factor yang menentukan tercapainya output yang berkualitas atau tidak. Akan tetapi dalam mengikuti rangkaian pembelajaran, mahasiswa masih dipengaruhi oleh berbagai faktor, baik faktor internal maupun faktor eksternal. Motivasi belajar merupakan faktor yang tidak bias diabaikan pengaruhnya. Menurut Mayliana \& Sofyan (2013), menyatakan bahwamotivasibelajar merupakan salah satu aspek kunci pembelajaran, dan juga menjadi sumber penting perbedaan di antara mahasiswa. Sedangkan menurut Slameto (2014) Motivasi merupakan faktor yang berpengaruh cukup besar terhadap prestasil belajar.

Peneliti memilih perguruan tinggi kampus STKIP PGRI Situbondo sebagai lokasi dan subjek penelitian, karena mahasiswa adalah elemen yang memiliki wawasan yang cukup luas dan selalu berusaha menjalani hidup lebih bijaksana dan peka terhadap orang dan lingkungan sekitar. Pertimbangan lain yang menjadikan mahasiswa sebagai subjek penelitian adalah karena mahasiswa merupakan khalayak yang sangat aktif dalam menggunakan media massa baik cetak maupun elektronik dan dari kategoriusia, mahasiswa termasuk kedalam mayoritas pengguna internet Sebagai media pembelajaran. Alasan lain peneliti memilih kampus STKIP PGRI Situbondo sebagai subjek penelitian adalah karena lebih efektif dan efisien. Efektif karena mereka lebih mudah untuk ditemui dan peneliti juga lebih mudah untuk berinteraksi dengan mereka, Efisien karena peneliti juga merupakan bagian dari mahasiswa STKIP PGRI Situbondo sehingga tidak mengeluarkan biaya yang cukup besar dalam penelitian ini.

\section{METODE}


Penelitian ini merupakan penelitian jenis penelitian kuantitatif. Dalam penelitian kuantitatif, masalah yang dibawa oleh peneliti sudah jelas (Sugiyono, 2016:30). Dalam Penelitian ini peneliti menggunakan rancangan penelitian ex post facto. Penelitian disebut ex post facto karena para peneliti berhubungan dengan variabel yang telah terjadi dan mereka tidak perlu memberikan perlakuan terhadap variabel yang diteliti. Teknik penentuan lokasi yang digunakan oleh peneliti adalah purposive sampling area. Penelitian ini dilakukan di STKIP PGRI Situbondo Situbondo. Adapun populasi dalam penelitian mahasiswa semester 2, 4 dan 6 program studi pendidikan ekonomi. Teknik analisis data yang dilakukan yaitu uji validitas dan reabilitas kemudian dilanjutkan dengan uji chi kuadrat.

\section{HASIL DAN PEMBAHASAN}

\section{ANALISIS DATA}

Untuk mengetahui ada tidaknya pengaruh pembelajaran online terhadap motivasi belajar mahasiswa maka menggunakan rumus analisis chi kuadrat langkahlangkah yang dilakukan dalam menganalisa data sebelum menganalisis melakukan uji validitas dan reliabilitas hasil angket.

\section{Uji Instrumen}

\section{a. Uji Validitas}

Uji validitas dilakukan pada seluruh pernyataan dalam instrumen dengan cara mengkorelasikan skor tiap pertanyaan dengan skor totalnya. Teknik korelasi yang digunakan adalah korelasi Product Moment. Data diolah dengan bantuan Microsoft Excel. Hasil uji validitas terhadap skor-skor variabel adalah sebagai berikut:

Tabel 1. Hasil Uji Validitas Pembelajaran Online

\begin{tabular}{|c|c|c|c|c|}
\hline Variabel & $\mathrm{r}_{\text {hitung }}$ & $\begin{array}{c}\mathrm{r}_{\text {tabel }} 5 \% \\
(\mathrm{db}=100)\end{array}$ & Interpretasi & Keputusan \\
\hline \multicolumn{2}{|c|}{ Pembelajaran Online $(\mathrm{X})$} \\
\hline 1 & 0,688 & 0,320 & Valid & Dipakai \\
\hline 2 & 0,659 & 0,320 & Valid & Dipakai \\
\hline 3 & 0,486 & 0,320 & Valid & Dipakai \\
\hline
\end{tabular}




\begin{tabular}{|c|c|c|c|c|}
\hline 4 & 0,574 & 0,320 & Valid & Dipakai \\
\hline 5 & 0,638 & 0,320 & Valid & Dipakai \\
\hline 6 & 0,650 & 0,320 & Valid & Dipakai \\
\hline 7 & 0,675 & 0,320 & Valid & Dipakai \\
\hline 8 & 0,124 & 0,320 & Tidak Valid & Tidak dipakai \\
\hline 9 & 0,789 & 0,320 & Valid & Dipakai \\
\hline 10 & 0,336 & 0,320 & Valid & Dipakai \\
\hline
\end{tabular}

Sumber Data: Hasil Uji validitas pada lampiran

Dari masing-masing hasil nilai korelasi tersebut, kemudian dikonsultasikan dengan nilai $\mathrm{r}$ tabel pada taraf signifikansi $5 \%$ dan pada $\mathrm{db}=\mathrm{N}-1=39-1=38$, dimana $r$ tabelnya $\left(r_{\text {tab }}\right)$ sebesar 0,320 , sehingga dapat dilihat. Jika besar $r$ hitung ( $\left.\mathrm{r}_{\text {hit }}\right)$ lebih kecil daripada $\mathrm{r}$ tabel $\left(\mathrm{r}_{\mathrm{tab}}\right.$ ), maka soal tersebut tidak valid dan tidak dipakai, tetapi apabila $\mathrm{r}$ hitung $\left(\mathrm{r}_{\mathrm{hit}}\right)$ lebih besar daripada $\mathrm{r}$ tabel $\left(\mathrm{r}_{\mathrm{tab}}\right)$ maka soal tersebut dapat dikatakan valid.

Tabel 2. Hasil Uji Validitas Y (Motivasi Belajar)

\begin{tabular}{|c|c|c|c|c|}
\hline Variabel & rhitung & $\begin{array}{l}\mathrm{r}_{\text {tabel }} 5 \% \\
(\mathrm{db}=100)\end{array}$ & Interpretasi & Keputusan \\
\hline \multicolumn{4}{|c|}{ Motivasi Belajar } & \\
\hline 1 & 0,426 & 0,320 & Valid & Dipakai \\
\hline 2 & 0,647 & 0,320 & Valid & Dipakai \\
\hline 3 & 0,714 & 0,320 & Valid & Dipakai \\
\hline 4 & 0,454 & 0,320 & Valid & Dipakai \\
\hline 5 & 0,463 & 0,320 & Valid & Dipakai \\
\hline 6 & 0,383 & 0,320 & Valid & Dipakai \\
\hline 7 & 0,583 & 0,320 & Valid & Dipakai \\
\hline 8 & 0,560 & 0,320 & Valid & Dipakai \\
\hline 9 & 0,629 & 0,320 & Valid & Dipakai \\
\hline 10 & 0,489 & 0,320 & Valid & Dipakai \\
\hline
\end{tabular}

Sumber Data: Hasil Uji validitas pada lampiran 
Dari masing-masing hasil nilai korelasi tersebut, kemudian dikonsultasikan dengan nilai $\mathrm{r}$ tabel pada taraf signifikansi $5 \%$ dan pada $\mathrm{db}=\mathrm{N}-1=39-1=38$, dimana $r$ tabelnya ( $\mathrm{r}_{\text {tab}}$ ) sebesar 0,320, sehingga dapat dilihat. Jika besar $\mathrm{r}$ hitung ( $\left.\mathrm{r}_{\text {hit }}\right)$ lebih kecil daripada $\mathrm{r}$ tabel $\left(\mathrm{r}_{\text {tab}}\right.$ ), maka soal tersebut tidak valid dan perlu direvisi, tetapi apabila $\mathrm{r}$ hitung ( $\mathrm{r}_{\text {hit }}$ ) lebih besar daripada $\mathrm{r}$ tabel $\left(\mathrm{r}_{\mathrm{tab}}\right)$ maka soal tersebut dapat dikatakan valid dan dapat digunakan.

\section{b. Uji Reliabilitas}

Uji reliabilitas bertujuan untuk mengetahui keandalan kuesioner yaitu sejauh mana suatu alat pengukur dapat dipercaya atau diandalkan dan tetap konsisten jika dilakukan dua kali atau lebih pada kelompok yang sama dengan alat ukur yang sama. Pengujian Cronbach Alpha digunakan untuk menguji tingkat keandalan (reliability) dari masing-masing angket variabel. Data diolah dengan bantuan Microsoft Excel. Hasil uji validitas terhadap skor-skor variabel adalah sebagai berikut:

Tabel 3. Hasil Uji Reliabilitas

\begin{tabular}{|l|c|c|c|}
\hline \multicolumn{1}{|c|}{ Variabel } & Koefisien Alpha & $\begin{array}{c}\mathrm{R} \text { tabel } \\
5 \%\end{array}$ & Interpretasi \\
\hline Pembelajaran Online & 0,874 & 0,320 & Reliabel \\
\hline Motivasi Belajar & 0,961 & 0,320 & Reliabel \\
\hline
\end{tabular}

Sumber Data: Hasil uji reliabilitas pada lampiran 7 dan 8

Dari hasil perhitungan Alpha Cronbach tersebut dikonsultasikan pada $r$ tabel dengan taraf signifikansi $5 \%$ dan pada $\mathrm{db}=\mathrm{N}-1=39-1=38$ yang besarnya $=$ 0,320, maka dapat dikatakan instrumen tersebut reliabel, karena nilai $\mathrm{r}$ hitung lebih besar dari nilai $r$ tabel pembelajaran online $(0,874>0,320)$ begitu juga dengan motivasi belajar $(0,961>0,320)$.

\section{HASIL}

Untuk mengetahui sejauh mana pengaruh pembelajaran online dengan motivasi belajar mahasiswa, analisis data dan pengujian hipotesis dengan menghitung korelasi antara $\mathrm{x}$ dan $\mathrm{y}$ : 
Untuk mengetahui apakah hipotesis diterima atau ditolak, maka harga chi kuadrat dibandingkan dengan harga kritik chi kuadrat. Hasil pengujian hipotesis selengkapnya adalah sebagai berikut: Harga $\mathrm{r}$-tabel $\left(\mathrm{X}^{\mathbf{2}}\right)$ dengan derajat kebebasan $(\mathrm{db})=1$ pada tabel taraf signifikasi $5 \%=3,841$. Sedangkan harga rhitung sebesar $=$ 11,4. Jadi harga $r_{\text {hit }}$ 11,4> harga $r_{\text {tab }} 3,841$, Jadi $r_{h i t}$ lebih besar dari $r_{\text {tab }}$ artinya hipotesa nihil (Ho) ditolak, dan hipotesa kerja (Ha) diterima, berarti " Ada pengaruh pembelajaran online terhadap motivasi belajar mahasiswa semester genap Program Studi Pendidikan Ekonomi tahun akademik 2020/2021.".

Berdasarkan hasil analisis diatas, maka nilai $\mathrm{KK}$ sebesar $=0,47$ tersebut penulis konsultasikan dengan tabel interpretasi koefisien korelasi. Setelah dikonsultasikan dengan tabel interpretasi diatas maka nilai 0,47 terletak antara $\pm 0,41$ s.d $\pm 0,60$. maka tingkat korelasi pengaruh pembelajaran online terhadap motivasi belajar mahasiswa ialah korelasi sedang.

\section{PEMBAHASAN}

Setelah hasil penelitian, analisa data, dan pengujian hipotesis kemudian dilakukan pembahasan hasil analisis data, pembahasan analisis data. Pada penelitian ini menunjukkan bahwa terdapat pengaruh signifikan pembelajaran online terhadap motivasi belajar mahasiswa. Hal ini dibuktikan dari hasil analisis yang menggunakan korelasi sederhana product moment diperoleh nilai koefisien korelasi sebesar 0,47. Setelah dikonsultasikan dengan tabel interpretasi diatas maka nilai 0,44 terletak antara $\pm 0,41$ s.d $\pm 0,60$ maka tingkat korelasi antara pengaruh pembelajaran online terhadap motivasi belajar mahasiswa ialah korelasi sedang.

Untuk mengetahui apakah hipotesis diterima atau ditolak, maka harga chi square dibandingkan dengan harga kritik chi square. Hasil pengujian hipotesis selengkapnya adalah sebagai berikut : Harga rtabel $\left(\mathrm{X}^{2}\right)$ dengan derajat kebebasan $(\mathrm{db})=1$ pada tabel taraf signifikasi $5 \%=3,841$. Sedangkan harga $\mathrm{r}_{\text {hit }}$ sebesar $=11,59$. Jadi harga $r_{h i t} 11,59>$ harga $r_{\text {tab }} 3,841$, Jadi $r_{h i t}$ lebih besar dari $r_{\text {tab }}$ artinya hipotesis nihil (Ho) ditolak, dan hipotesis kerja (Ha) diterima, berarti " Ada pengaruh pembelajaran online terhadap motivasi belajar mahasiswa".

\section{8 | JURNAL IKA PGSD UNARS VOL. 10 No. 2 DESEMBER 2021}


Jadi, pembelajaran online adalah pembelajaran yang dilakukan melalui jaringan internet. Oleh karena itu, dalam Bahasa Indonesia pembelajaran online diterjemahkan sebagai 'pembelajaran dalam jaringan' atau 'pembelajaran online'. Istilah online learning banyak disinonimkan dengan istilah lainnya seperti e-learning, internet learning, web-based learning, tele-learning, dis- buku pembelajaran online tributed learning dan lain sebagainya (Ally, 2008). Dalam beberapa tahun terakhir, pembelajaran online juga sering dikaitkan dan digunakan sebagai pada istilah mobil elearning atau m-learning, yang merupakan pembelajaran online melalui perangkat komunikasi bergerak (mobil ecommunication devices) seperti computer tablet dan smart phone. tributed learning dan lain sebagainya (Ally, 2008).

\section{KESIMPULAN}

Setelah penulis menganalisa semua data yang diperoleh dari hasil penelitian tentang pengaruh pembelajaran online terhadap motivasi belajar mahasiswa, maka penulis dapat mengambil kesimpulan dari pengumpulan data, analisis data, dan pengujian hipotesis yang penulis lakukan, maka dapat disimpulkan bahwa: Ada pengaruh pembelajaran online terhadap motivasi belajar mahasiswa semester genap Program Studi Pendidikan Ekonomi tahun akademik 2020/2021 sebesar 0,47 merupakan korelasi sedang

\section{DAFTAR DAFTAR}

Albert Efendi Pohan. (2020). KONSEP PEMBELAJARAN DARING BERBASIS PENDEKATAN ILMIAH (Albert Efendi Pohan (Ed.); Pertama). CV. SARNU UNTUNG.

Albi Anggita \& johan Setiawan. (2018). METODOLOGI PENELITIAN KUALITATIF (Ella Defi Lestari (Ed.); 1st ed.). CV Jejak.

Conni R, S. (2010). Metode Penelitian Kualitatif Jenis, Karakteristik, dan Keunggulannya (Arita L (Ed.); 1st ed.). GRASINDO.

Dwi, B., Amelia, A., Hasanah, U., \& Putra, A. M. (2020). Analisis Keefektifan Pembelajaran Online di Masa Pandemi Covid-19. Jurnal Pendidikan Guru Sekolah Dasar, 2(1), 20.

Fahmi Arifin. (2019). MANAJEMEN PEMBELAJARAN DALAM UPAYA PENINGKATAN HASIL BELAJAR SISWA PADA PESANTREN MODERN DARUL 'ULUM KOTA BANDA ACEH. Learning Management Ahd Learning Outcomes, 10(2), 150.

Firman, F., \& Rahayu, S. (2020). Pembelajaran Online di Tengah Pandemi Covid-19. 
Indonesian Journal of Educational Science (IJES), 2(2), 81-89. https://doi.org/10.31605/ijes.v2i2.659

Irjus Indrawan. (2020). GURU SEBAGAI AGEN PERUBAHAN (Najamuddin (Ed.); 1st ed.). Lakeisha.

Kadek Ayu Astiti. (2017a). EVALUASI PEMBELAJARAN (Ratih (Ed.); 1st ed.). ANDI.

Magdalena, I. (2021a). RAGAM TULIS DESAIN PEMBELAJARAN SD (Hani Wijay). CV Jejak, anggota IKAPI.

Magdalena, I. (2021b). RAGAM TULIS DESAIN PEMBELAJARAN SD (Arif Yupiter (Ed.)). CV Jejak, anggota IKAPI.

Mayasari, S., \& Angguntiara, C. (2018). Strategi Humas PT Pelayaran Nasional Indonesia (Persero) Dalam Membuat Tabloid Sebagai Media Informasi Publik $\begin{array}{llll}\text { Internal. Jurnal } & \text { Komunikasi, } & 9(1), & \end{array}$ https://ejournal.bsi.ac.id/ejurnal/index.php/jkom/article/view/3405/2333

Mayliana, E., \& Sofyan, H. (2013). Penerapan accelerated learning dengan pendekatan SAVI untuk meningkatkan motivasi dan hasil belajar kompetensi menggambar busana. Jurnal Pendidikan Vokasi, 3(1), 19. https://doi.org/10.21831/jpv.v3i1.1573

Michael Jibrael Rorong (Ed.). (2020). Michael Jibrael Rorong (1st ed.). CV. BUDI UTAMA.

Putranti, N. (2013). Cara Membuat Media Pembelajaran Online Menggunakan Edmodo. Jurnal Pendidikan Informatika Dan Sains, 2(2), 139-147. https://journal.ikippgriptk.ac.id/index.php/saintek/article/view/224/223

Rais, M. (2010). Model Project Based-Learning Sebagai Upaya Meningkatkan Prestasi Akademik Mahasiswa. Jurnal Pendidikan Dan Pengajaran, 43(3), 3.

Rijali, A. (2019). Analisis Data Kualitatif [Qualitative Data Analysis]. Alhadharah: Jurnal Ilmu Dakwah, 17(33), 81.

Riyanto, Y. (2014). PARADIGMA BARU PEMBELAJARAN (Yatim Riyanto (Ed.); 4th ed.). KENCANA.

Ruslan dan Rusli Yusuf. (2017). PERENCANAAN PEMBELAJARAN PPKn (1 (Ed.); Fatahullah). syiah Kuala University Press.

S Nassutions. (2011). PENGARUH MOTIVASI BELAJAR SISWA TERHADAP PESTASI BELAJAR IPA DI SEKOLAH DASAR. Journal Penelitian Pendidikan, 13(1).

Slameto. (2014). Pengaruh Motivasi Belajar Dan Aktivitas Belajar Terhadap Hasil Belajar Akuntansi. Jurnal Pendidikan Ekonomi, 4(1), 1.

Sobry Sutikno. (2021). STRATEGI PEMBELAJARAN (Nurlaeli (Ed.); 1st ed.). CV.Adanu Abimata.

Surtinah tirtinegoro. (2012). Hubungan Kebiasaan Belajar Dengan Prestasi Belajar Siswa Kelas Vii B Smp Negeri 13 Malang. Journal of Chemical Information and Modeling, 53(9), 9.

Tuken, R. (2013). IbM ALAT BANTU DAN SUMBER BELAJAR DALAM PEMBELAJARAN PKn DI SEKOLAH DASAR PADA GURU-GURU SEKOLAH DASAR YANG STUDI LANJUT DI PGSD UPP PAREPARE. 
Jurnal Publikasi Pendidikan, III(1), 62-66.

Zebua, S. (2020). SIBERNETIK DALAM KUALITAS PEMBELAJARAN PENDIDIKAN AGAMA KRISTEN (Arif Yupit). Lakeisha (Anggota IKAPI No.181/JTE/2019). 